\title{
KESANTUNAN BERBAHASA PERANGKAT DESA PONDOK PABRIK KOTA LANGSA
}

\author{
Widia Tamara ${ }^{1}$, Joko Hariadi, Prima Nucifera \\ ${ }^{1}$ Mahasiswa Program Studi Bahasa Indonesia, FKIP Universitas Samudra \\ ${ }^{1}$ widiatamara97@gmail.com
}

\section{Info Artikel:}

Diterima:

Disetujui:

Dipublikasikan:

\section{Abstract}

The purpose of this study was to describe the politeness of the language of the Pondok Pabrik Kota Langsa village. The research data were in the form of speech acts of conversations at the village officials meeting at Pondok Pabrik Kota Langsa that were used in the meeting. The data source of this research is the Pondok Pabrik Kota Langsa. The population of this study is 15 people in Pondok Pabrik Kota Langsa. The sample in this study took all members of the population as samples if the population is below 30 people. Data analysis was performed by using descriptive qualitative methods. Data collection techniques using the method of observation, recording techniques, note -taking techniques and documentation. Based on the results of the research that has been analyzed, it was found that there are still many utterances from the Pondok Pabrik Kota Langsa, which meet the value of politeness. The results of the analysis that have been obtained show that the speech act of politeness in the language of the Pondok Pabrik Kota Langsa that contains the maxim of agreement is more dominant than the maxim of wisdom, the maxim of generosity, the maxim of praise, the maxim of sympathy and the maxim of simplicity. This is because of the situation of the meeting aims to solve or find a way out of a problem that must be negotiated / discussed by deliberation and found a little speech that violates the principle of politeness in language.

Keywords: Politeness In Language, Village Officials, Pondok Pabrik village, Langsa City

Abstrak
Tujuan penelitian ini adalah mendeskripsikan kesantunan
berbahasa perangkat desa Pondok Pabrik Kota Langsa. Data
penelitian berupa tindak tutur percakapan rapat dinas
perangkat desa Pondok Pabrik Kota Langsa yang digunakan
dalam rapat.Sumber data penelitian ini adalah perangkat
Desa Pondok Pabrik Kota Langsa. Populasi penelitian ini


adalah perangkat desa Pondok Pabrik Kota Langsa yang berjumlah 15 orang. Sampel penelitian ini adalah 15 orang perangkat desa Pondok Pabrik Kota Langsa. Sampel pada penelitian ini mengambil semua populasi karena menggunakan sampel jenuh yang mengambil semua anggota populasi sebagai sampel apabila populasi dibawah 30 orang. Analisis data dilakukan dengan metode kualitatif yang bersifat deskriptif. Teknik pengumpulan data menggunakan metode observasi, teknik rekam, teknik catat dan dokumentasi. Berdasarkan hasil penelitian yang telah dianalisis ditemukan bahwa masih banyak tuturan perangkat desa Pondok Pabrik Kota Langsa yang memenuhi nilai kesantunan. Hasil analisis yang telah didapat menunjukkan bahwa tindak tutur kesantunan berbahasa perangkat desa Pondok Pabrik Kota Langsa yang mengandung maksim kesepakatan lebih dominan dibandingkan maksim kebijaksanaan, maksim kedemawanan, maksim pujian, maksim kesimpatian dan maksim kesederhanaan. Hal ini dikarenakan pada situasi rapat bertujuan untuk memecahkan atau mencari jalan keluar suatu masalah yang harus dirundingkan/didiskusikan secara bermusyawarah serta ditemukan sedikit tuturan yang melanggar prinsip kesantunan berbahasa.

Kata Kunci : Kesantunan Berbahasa, Perangkat Desa, Desa Pondok Pabrik, Kota Langsa

\section{Pendahuluan}

Pondok Pabrik adalah sebuah desa yang terletak di kecamatan Langsa Lama, kota Langsa, Aceh, Indonesia. Pada tahun 2010, desa ini dimekarkan untuk membentuk desa Sukajadi Kebun Ireng dengan luas 684 Ha dan jumlah penduduk 2283 jiwa. Saat ini pemerintahan desa di Pondok Pabrik di pimpin oleh Geuchik Noto yang di bantu oleh 12 perangkat desa dengan latar belakang pendidikan yang berbeda. Penggunaan bahasa Indonesia yang santun bermartabat yang dipakai di lingkungan pemerintahan desa, sebagai salah satu lingkungan pemerintahan Pemerintah desa merupakan lembaga pemerintah yang bertugas mengelola pemerintahan di wilayah tingkat desa. Berdasarkan hasil wawancara dengan kepala desa Pondok Pabrik, kepala desa berwenang untuk mengajukan rancangan peraturan desanya sendiri yang sesuai dengan UU, membina kehidupan, perekonomian masyarakat desa hingga mengordinasikan segala elemen yang ada dalam melakukan pembangunan desa secara partisipatif untuk kemajuan dan kepentingan desa melalui rapat rapat yang dilakukan secara periodik sesuai anggaran yang ditetapkan yaitu 4 kali dalam sebulan. Selain itu di hadiri oleh kepala seksi pada pemerintahan desa rapat juga di hadiri oleh utusan atau kepala dusun.

Perbedaan latar belakang pendidikan, sosial menyebabkan sering terjadi debat yang terkadang melanggar nilai-nilai kesantunan dalam berbahasa. Pada saat observasi penelitian yang 
peneliti lakukan pada saat rapat di desa Pondok Pabrik, peneliti melihat ada beberapa pelanggaran prinsip kesantunan berbahasa yang dilakukan oleh peserta rapat yaitu, kritik kepada lawan tutur secara langsung pada saat rapat dengan memotong pembicaraan. Kemudian penutur ketika bertutur disertai dengan dorongan rasa emosi yang begitu berlebihan sehingga ada kesan bahwa penutur marah kepada lawan tuturnya. Penutur ketika bertutur seringkali bersifat protektif terhadap pendapatnya. Hal ini dilakukan agar tuturan lawan tutur tidak dipercaya oleh pihak lain. Penutur ingin memperlihatkan pada orang lain bahwa pendapatnya benar, sedangkan pendapat mitra tutur salah. Tuturan seperti itu akan dianggap tidak santun dan penutur dengan sengaja ingin memojokkan lawan tutur dan membuat lawan tutur tidak berdaya. Tuturan yang disampaikan penutur menjadikan lawan tutur tidak dapat melakukan pembelaan.

Penelitian kesantunan berbahasa perangkat Desa Pondok Pabrik Kota Langsa sangat menarik untuk diteliti karena dalam penggunaannya bahasa yang digunakan mempunyai banyak medan makna yang positif serta tuturantuturannya yang memperhatikan ramburambu kesantunan sehingga tuturantuturannya perlu dimaknai secara mendalam, bagaimana penutur mengatur penggunaan bahasanya sehingga maksud dari penyampai pesan dapat tersampaikan dengan baik. Pada penelitian ini ramburambu kesantunan berbahasa yang digunakan yaitu berdasarkan teori kesantunan Leech yang dijabarkan dalam bentuk maksim atau ketentuan. Maksim yang dikemukakan ada enam, yaitu (1) maksim kebijaksanaan, (2) maksim penerimaan, (3) maksim penghargaan, (4) maksim kerendahan hati, (5) maksim kesetujuan, (6) maksim kesimpatian. Tiaptiap maksim tersebut dijabarkan secara rinci berikut ini (dalam Rahardi menurut Leech, 2010:59). (1) Maksim kebijaksanaan menghendaki penutur dan lawan tutur harus meminimalkan kerugian dan memaksimalkan keuntungan bagi orang lain. (2) Maksim penerimaan/kedermawanan menghendaki penutur dan lawan tutur memaksimalkan kerugian bagi dirinya sendiri dan meminimalkan keuntungan diri sendiri. (3) Maksim Penghargaan/pujian menghendaki penutur dan lawan tutur memaksimalkan rasa hormat kepada orang lain dan meminimalkan rasa tidak hormat kepada orang lain. (4) Maksim kerendahan hati/kesederhanaan menghendaki memaksimalkan ketidakhormatan kepada lawan tutur dan meminimalkan rasa hormat kepada diri sendiri. (5) Maksim kecocokan/kesepakatan menghendaki penutur dan lawan tutur memaksimalkan kesetujuan di antara mereka dan meminimalkan ketidaksetujuan di antara mereka. (6) Maksim kesimpatian menghendaki penutur dan lawan tutur memaksimalkan rasa simpati dan meminimalkan rasa antipati kepada lawan tuturnya. Berdasarkan pemaparan di atas dalam rangka memahami kesantunan berbahasa sebagai aspek yang paling penting dalam menjalin komunikasi agar tidak menimbulkan kesalahpahaman pada saat bertutur dan saling menguntungkan karena adanya rasa solidaritas dan saling menghargai, perlu dilakukan penelitian yang berorientasi pada aspek strategi kesantunan berbahasa yang akan memungkinkan pembaca melihat kaidah kesantunan yang perlu dipatuhi agar tuturan terdengar santun. Akibat dari ketidaksantunan dalam berkomunikasi tersebut, dapat mencerminkan sikap atau karakter yang tidak santun. Dengan tidak adanya kesantunan dalamberkomunikasi juga yang digunakan oleh masyarakat dalam interaksi sosial dapat membuat mitra tutur (lawan komunikasi) dalam hal ini perangkat desa merasa tidak dihargai dengan adanya penggunaan bahasa yang tidak santun tersebut.

Kesantunan berbahasa pada hakikatnya erat dengan hubungan sosial dalam masyarakat. Kesantunan berbahasa 
merupakan pengungkapan gagasan, ide atau pendapat untuk saling membina kecocokan atau kemufakatan di dalam kegiatan bertutur yang disertai dengan etika serta perilaku yang baik menurut norma-norma sosial budaya yang berlaku dalam masyarakat. Kesantunan (politeness) sebagai perilaku yang secara aktif mengekspresikan hal positif kepada orang lain, juga perilaku menjauhi halhal yang tidak mengesankan/mengenakkan.

Kesantunanberbahasa dapat diekspresikan secara verbal ataunonverbal, atau cara-cara yang dipakai untukmengekspresikan kesantunan melaluipenggunaan bahasa.

Mislikhah (2014:287) menyebutkan bahwa "Kesantunan (politiness), kesopansantunan, atau etiket adalah tatacara, adat, atau kebiasaan yang berlaku dalam masyarakat." Kesantunan merupakan aturan perilaku yang ditetapkan dan disepakati bersama oleh suatu masyarakat tertentu sehingga kesantunan sekaligus menjadi prasyarat yang disepakati oleh perilaku sosial. Oleh karena itu, kesantunan ini biasa disebut "tatakrama." Lebih lanjut Rahardi (2010:38) menyebutkan "Apabila kejelasan pragmatik dikaitkan dengan kesantunan, maka semakin jelas maksud sebuah tuturan akan semakin tidak santunlah tuturan itu, demikian sebaliknya, semakin tidak tembus pandang maksud suatu tuturan akan menjadi semakin santunlah tuturan itu." Dengan perkataan lain, penggolongan tindak tutur ke dalam bentuk-bentuk tutur itu akan memungkinkan dapat teridentifikasi peringkat kesantunan tuturan dalam kegiatan bertutur. Sedangkan Yule (2014:3) menyatakan bahwa "Pragmatik adalah studi tentang makna yang disampaikan oleh penutur dan di tafsirkan oleh pendengar atau pembaca."

Pandangan kesantunan yang berkaitan dengan norma-norma sosial (the social-norm view). Di dalam pandangan ini, kesantunan dalam bertutur ditentukan berdasarkan norma-norma sosial dan kultural yang ada serta berlaku di dalam masyarakat bahasa itu. Dengan kata lain, kita berbicara harus menyesuaikan dengan konteks. Menurut Hartanti (2016:1) menyatakan bahwa Etika berbahasa merupakan subsistem dari kebudayaan, hal ini terbukti dengan kemampuan seseorang dalam berbahasa diukur melalui pengetahuannya mengenai suatu budaya dalam suatu masyarakat tempat ia tinggal. Melalui budaya yang ia pelajari ia akan dapat dengan mudah menggunakan bahasa sesuai dengan tata cara atau etika berbahasa yang berlaku di masyarakat tersebut. Lebih lanjut Suhartono (2016:168) berpendapat etika adalah instrumen dalam masyarakat untuk menuntun tindakan (perilaku) agar mampu menjalankan fungsi dengan baik dan dapat lebih bermoral. Hal tersebut berarti bahwa etika merupakan norma dan aturan yang mengatur perilaku seseorang dalam bertindak dan memainkan perannya sesuai dengan aturan main yang ada dalam masyarakat agar tindakannya dapat disebut santun atau bermoral. Bahasa beretika merupakan bagian dari "assurance" yaitu bahasa santun, bahasa dengan pilihan kata sesuai dengan status lawan bicara. Apa yang dimaksud dengan santun di dalam bertutur, dapat disejajarkan dengan etiket berbahasa (language etiquette). Perlu diketahui bahwa kemampuan serta tingkat kesantunan berbahasa Indonesia di kalangan masyarakat Indonesia masih sangat rendah. Buruknya kemampuan berbahasa Indonesia sebagian besar orang Indonesia, termasuk golongan elit dan golongan intelektualnya adalah karena adanya sifat-sifat negatif yang melekat pada sebagian besar orang Indonesia. Sifat-sifat negatif itu adalah suka meremehkan mutu, mental menerabas, tuna harga diri, tidak disiplin, enggan bertanggung jawab, dan suka latah atau ikut-ikutan. Kesantunan berbahasa dalam kehidupan masyarakat yang digunakan dalam interaksi antar manusia satu dengan 
yang lainnya dan akan berjalan damai jika masyarakat itu sendiri sadar akan kesantunan berbahasa, ungkapan dari bahasa yang kasar dan arogan sering kali menyebabkan perselisihan dan kesalahpahaman di kalangan masyarakat. Mereka yang pandai berbicara dapatdengan mudah menguasai forum pembicaraan. Banyak cara yang dapat dilakukan oleh pembicara agar berhasil menyampaikan gagasan mereka dengan baik sehingga mudah diterima oleh orang lain. Beberapa penelitian yang relevan dengan penelitian ini adalah penelitian dengan judul Kesantunan Berbahasa Mahasiswa dalam berinteraksi dengan Dosen di universitas Ahmad Dahlan: Analisis Pragmatik oleh Budiwati (2015:557) dengan hasil dari 35 data percakapan mahasiswa dan dosen dalam kedua media sosial tersebut, dapat diketahui bahwa komunikasi tertulis mahasiswa kepada dosen dalammedia sosial cenderung berbentuk informal dan terkesan santai dengan tanda-tanda: penggunaanbanyak singkatan, istilah informal/santai/alay, morfem terikat santai, dosen yang mudamemengaruhi sikap mahasiswa yang cenderung santai bahasanya, mahasiswa cenderungbersikap lebih santai dan kurang sopan saat berkomunikasi dengan dosen yang sama programstudinya, dibandingkan dengan dosen yang tidak sama prodinya dengan mahasiswa, dan bahasa yang lebih dan paling santun yang digunakan mengandung organisasi yang relatif lengkap, seperti salam pembuka, pengenalan nama, maksud, permohonan maaf, ucapan terimakasih, dan salam penutup.

Selanjutnya Mislikhah (2018:295) meneliti tentang Kesantunan Berbahasa dengan hasil kesantunan berbahasa tecermin dalam tatacara berkomunikasi lewat tanda verbal atau tatacara berbahasa. Ketika berkomunikasi, kita tunduk pada norma-norma budaya, tidak hanya sekedar menyampaikan ide yang kita pikirkan. Tata cara berbahasa harus sesuai dengan unsur-unsur budaya yang ada dalam masyarakat tempat hidup dan dipergunakannnya suatu bahasa dalam berkomunikasi. Senada dengan hal tersebut, Sartini (2017:23) melakukan penelitian yang berjudul Strategi Kesantunan Berbahasa Diaspora Orang Bali di Jawa Timur dalam Situasi Formal dengan hasil ditemukan bahwa Analisis terhadap kesantunan di atas menunjukkan bahwa kesantunan berbahasa disampaikan secara verbal. Kesantunan verbal bertujuan untuk (a) menciptakan atau memelihara hubungan sosial dengan menggunakan bahasa fatis; (b) melestarikan aturan etika sosial.

Dari analisis yang telah dilakukan dapat disimpulkan bahwa diaspora orang Bali di Jawa Timur menggunakan berbagai strategi dalam berbahasa. Strategi kesantunan berbahasa dipresentasikan lewat strategi kesantunan positif dan kesantunan negatif. Dalam konteks formal, kecenderungannya adalah penggunaan strategi kesantunan negatif. Kesantunan negatif juga ditandai dengan penggunaan bahasa Bali Alus. Pemarkah kesantunan (politeness marker) dan bahasa Bali Alus dalam hal ini tidak saja digunakan oleh orang yang tidak memiliki kekuasaan (-P) tetapi juga digunakan oleh orang yang memiliki status lebih tinggi, kekuasaan dan jabatan $(+\mathrm{P})$ kepada orang yang (-P). Ini menandakan bahwa masyarakat Bali tidak membedakan status dalam berbahasa. Ini merupakan salah satu strategi kesantunan dalam berbahasa yaitu sifat equality (ekualitas).

\section{Metode Penelitian}

Pendekatan penelitian yang digunakan dalam penelitian ini adalah pendekatan kualitatif dengan jenis penelitian deskriptif. Sugiyono (2018:8)“Metode penelitian kualitatif sering disebut metode peneltian naturalistik karena peneltiannya dilakukan pada kondisi yang alamiah (Natural setting)." Penelitian ini menggunakan pendekatan deskriptif menggunakan 
analisis dengan tujuan menjelaskan fenomena yang terjadi di masyarakat secara mendalam dan mengumpulkan data secara dalam dan lengkap. Sedangkan jenis penelitian adalah deskrpitifdengan cara mendeskripsikan bentuk kata-kata dan bahasa, pada konteks khusus alamiah dengan memanfaatkan berbagai metode ilmiah. Dalam penelitian ini akan digunakan pendekatan semantik, artinya peneliti sebagai penganalisis wacana mempertimbangkan makna kebahasaan yang muncul.

Selanjutnya Pratamanti (2017:238) meneliti tentang Kesantunan Berbahasa Dalam Pesan Whatsapp Yang Ditujukan Kepada Dosen dengan hasil bahwa tuturan yang digunakan oleh mahasiswa dalam komunikasi dengan dosen melalui whatsapp belum memiliki nilai kesantunan yang cukup baik. Hasil penelitian menunjukkan bahwa terdapat penyimpangan kesantunan dalam tuturan mahasiswa yang ditujukan kepada dosen melalui whatsapp. Penyimpangan kesantunan tersebut berupa penggunaan bahasa gaul (aku, kok, nggak), pembahasan diluar konteks perkuliahan, cara pengungkapan maksud yang tidak sopan dan penggunaan aspek paralinguistik yang tidak tepat. Mahasiswa cenderung menggunakan bahasa gaul karena terbiasa menggunakannya dalam kehidupan sehari-hari. Rata-rata mahasiswa menggunakan bahasa gaul meskipun dalam ragam bahasa formal atau nonformal. Selanjutnya Dari (2017:10) meneliti tentang Analisis Kesantunan Berbahasa Pada Kegiatan Pembelajaran Kelas VIII E SMPN 2 Kota Bengkulu Tahun Ajaran 2016/2017 dengan hasil penelitian menunjukkkan bahwa data penyimpangan prinsip kesantunan berbahasaterdiri dari empat maksim, meliputi maksim kebijaksanaan, penghargaan, kedermawanan,dan kesederhanaan.. Penyimpangan prinsip kesantunan berupa penyimpangan satu maksimdan dua maksim berbeda sekaligus dalam satu tuturan. Penyimpangan prinsip kesantunandua maksim terdiri atas penyimpangan prinsip kesantunan maksim kedermawanan dan penghargaan, kebijaksanaan dan kedermawanan, dan kebijaksanaan dan penghargaan. Selanjutnya, data pematuhan prinsip kesantunan berbahasa terdiri dari enam maksim, meliputi maksim kebijaksanaan, penghargaan, kedermawanan, kesederhanaan, permufakatan, dan kesimpatian. Pematuhan prinsip kesantunan berupa pematuhan satu maksim, dua maksim dan tiga maksim berbeda sekaligus dalam satu tuturan. Pematuhan prinsip kesantunan dua maksim terdiri atas pematuhan prinsip kesantunan maksim kebijaksanaan dan kedermawanan, kebijaksanaan dan kesederhanaan, penghargaan dan kebijaksanaan, penghargaan dan permufakatan, serta penghargaan dan kesederhanaan.

Sumber data dalam penelitian ini adalah tindak tutur percakapan rapat dinas antara perangkat desa dengan kepala desa yang dianggap memenuhi prinsip kesantunan. Penelitian ini dilakukan di desa Pondok Pabrik Langsa Lama Kota Langsa, sedangkan waktu penelitian adalah pada bulan September 2019.

Teknik pengumpulan data pada penelitian ini adalah metode observasi, metode rekam, metode catat dan metode dokumeentasi. Teknik rekam adalah pemerolehan data dengan cara merekam pemakaian bahasa lisan yang bersifat spontan. Alat perekam yang dipakai sebaiknya yang berukuran kecil, sehingga dapat dimasukkan ke dalam saku baju dan tidak diketahui oleh informan yang 
bahasanya kita rekam. Dengandemikian, informan dapat menyampaikan bahasa secara alamiah (Zaim, 2014:92)

Teknik pengumpulan data menjadi langkah yang paling penting dalam penelitian karena mengumpulkan data menjadi tujuan utama dalam penelitian. Alasan penulis menggunakan teknik tersebut karena data dalam penelitian diperoleh dari tindak tutur percakapan rapat dinas antara perangkat desa dengan kepala desa yang dianggap memenuhi prinsip kesantunan. Penelitian ini dilakukan di desa Pondok Pabrik Langsa Lama Kota Langsa. Hadi (dalam Sugiyono, 2018:145) "Observasi merupakan suatu proses yang komplek, suatu prosse yang tersusun berbagai proses biologis dan psikologis dua diantara yang terpenting adalah proses pengamatan dan ingatan." Data dalam penelitian ini diperoleh dengan cara: (1) melihat dan mendengar rekaman vidio observasi dalam penelitian tindak tutur percakapan rapat dinas antara perangkat desa dengan kepala desa yang dianggap memenuhi prinsip kesantunan. Penelitian ini dilakukan di desa Pondok Pabrik Langsa Lama Kota Langsa. (2) mencatat data-data tentang kesantunan berbahasa yang terdapat pada Perangkat Desa Pondok Pabrik Langsa Lama Kota Langsa.

Teknik analisis data yang digunakan dalam penelitian ini adalah (1) Pemeriksaan data (editing), dalam hal ini peneliti mengoreksi apakah data yang terkumpul sudah cukup lengkap, benar dan sesuai dengan masalah. (2) Penandaan data (Coding), dalam hal ini peneliti memberikan catatan atau tanda yang menyatakan jenis sumber data seperti buku, literatur, perundang-undangan atau dokumen. (3) Klasifikasi data (classification), dalam hal ini peneliti mengelompokkan data yang melalui proses pemeriksaan serta penggolongan data. (4) Penyusunan data ( systematizing), yaitu menyusun data yang telah diperiksa secara sistimatis sesuai dengan urutannya sehingga pembahasan lebih mudah dipahami. (5) Analisa Data yaitu menganalisa data berupa hasil rekaman video rapat antara perangkat desa dengan kepala desa berdasarkankaidah kesantunan menurut oleh Leech. (6) Penarikan kesimpulan (Verification). Kesimpulan awal yang dikemukakan masih bersifat sementara, dan akan berubah bila tidak ditemukan bukti-bukti yang kuat dan mendukung pada tahap pengumpulan data berikutnya. Tetapi apabila kesimpulan yang dikemukakan pada tahap awal, didukung oleh bukti-bukti yang valid dan konsisten saat peneliti kembali kelapangan mengumpulkan data. Sugiyono (2018:244) menyatakan bahwa "Analisis data adalah proses mencari dan menyusun secara sitematis data yang diperoleh dari hasil wawancara, catatan lapangan dan dokumentasi, dengan cara mengorganisasikan data ke dalam kategori, menjabarkan kedalam unit-unit, melakukan sintesa, memilih yang akan di pelajari, membuat kesimpulan sehingga mudah di pahami." Jadi analisis data adalah proses mencari menyusun data-data yang terkumpul di lapangan kemudian dilakukan analisis ilmiah dan membuat kesimpulan.

\section{Hasil Dan Pembahasan}

Data dari penelitian ini diperoleh dari tindak tutur percakapan rapat dinas antara perangkat desa dengan kepala desa yang dianggap memenuhi prinsip kesantunan. Penelitian ini dilakukan di desa Pondok Pabrik Langsa Lama Kota Langsa. Berdasarkan hasil penelitian yang diperoleh peneliti, menunjukkan bahwa kesantunan berbahasa Perangkat Desa Pondok Pabrik Kota Langsa sangat baik. Berdasarkan hasil penelitian ditemukan sebanyak 25 maksim berupa tuturan yang terdiri atas 6 maksim kesantunan berdasarkan teori Leech yaitu (1) Maksim kebijaksanaan,

Kedermawanan,

Pujian/penghargaan,

Maksim Kesederhanaan, (5) Maksim kesepakatan dan (6) Maksim kesimpatian. Berdasarkan 
data yang diperoleh pada rapat ke-1 hari Jumat tanggal 20 September 2019 jam 7.00 tentang "Kinerja Aparat Desa" diperoleh 9 maksim. Rapat ke-2 hari Selasa tanggal 1 Oktober 2019 jam 8.00 tentang "Jumat Bersih" diperoleh 8 maksim. Rapat ke-3 hari Senin tanggal 7 Oktober 2019 jam 3.00 tentang "Kelengkapan Data Administrasi" diperoleh 6 masksim. Rapat ke-4 hari Rabu tanggal 9 Oktober 2019 jam 10.00 tentang "Qanun Gampong" diperoleh 2 maksim.

Berikut penjelasan mengenai data tuturan kesantunan berbahasa Perangkat Desa Pondok Pabrik Kota Langsa yang mengandung maksim kesantunan teori Leech pada penelitian ini dapat dilihat sebagai berikut:

1. Maksim Kebijaksanaan.

Prinsip kesantunan yang dikemukakan Leech dalam Rahardi (2010:59) tact maxim (maksim kebijaksanaan) adalah menggariskan bahwa setiap peserta penuturan harus meminimalkan kerugian orang lain, atau memaksimalkan keuntungan bagi orang lain. Kalau dalam tuturan penutur berusaha memaksimalkan keuntungan orang lain, maka lawan tutur harus pula memaksimalkan kerugian dirinya, bukan sebaliknya. Penjelasan mengenai wujud tuturan yang mengandung maksim kebijaksanaan antara perangkat desa dengan perangkat desa dapat dilihat pada data 1 dibawah ini.

Data 1

On/Rek/video_20190920_145754

Situasi : Rapat yang membahas tentang kinerja aparat desa

Waktu : 20 September 2019/ 07:11

"Bagaimana cara kita melayani masyarakat jika masyarakat membutuhkan, kita tidak ada di tempat".

Tuturan tersebut disampaikan oleh bapak Suparno Sekdes Desa Pondok
Pabrik di depan perangkat Desa Pondok Pabrik . Tuturan seperti yang di atas mengandung maksim kebijaksanaan. Maksim kebijaksaan tersebut muncul ketika adanya keluhan untuk pengurusan surat surat terkadang sulit karena petugasnya tidak ada di tempat (Data 1) Bagaimana cara kita melayani masyarakat jika masyarakat membutuhkan, kita tidak ada di tempat. membuktikan bahwa Sekdes berusaha membuat kerugian pada masyarakat sekecil mungkin dan membuat keuntungan masyarakat sebesar mungkin. Dapat disimpulkan tuturan (1) mengandung maksim kebijaksanaan. Tuturan bapak Suparno Sekdes Desa Pondok Pabrik di respon peserta rapat dengan anggukan kepala.

2. Maksim Kedermawanan.

Prinsip kesantunan yang dikemukakan Leech dalam Rahardi (2010:59) Generosty maxim (maksim kedermawanan) adalah menghendaki setiap peserta petuturan untuk memaksimalkan kerugian bagi diri sendiri dan meminimalkan keuntungan diri sendiri. Penjelasan mengenai wujud tuturan yang mengandung maksim kedermawanan antara perangkat desa dengan perangkat desa lainnya dapat dilihat pada data 2 .

\section{Data 2 \\ On/Rek/video_20190920_145754 \\ Situasi : Rapat yang membahas tentang kinerja aparat desa \\ Waktu : 20 September 2019/08:25 \\ "Tolonglah di lihat jika ada warga yang susah di tolong kalau tidak bisa menolong segera laporkan ke Geuchik”.}

Tuturan tersebut disampaikan oleh bapak Suparno Sekdes Desa Pondok Pabrik di depan perangkat Desa Pondok Pabrik. Tuturan seperti yang di atas mengandung maksim kedermawanan. Maksim kedermawanan tersebut muncul merupakan tanggapan ataswacana bahwa masih ada masyarakat di desa Pondok 
Pabrik yang hidpnya susah. (Data 2) Tolonglah di lihat jika ada warga yang susah di tolong kalau tidak bisa menolong segera laporkan ke Geuchik. Membuktikan bahwa Sekdes Desa Pondok Pabrik berusaha memaksimalkan kerugian bagi diri sendiri dan meminimalkan keuntungan diri sendiri. Dapat disimpulkan tuturan (Data 2) mengandung maksim kedermawanan. Tuturan bapak Suparno Sekdes Desa Pondok Pabrik di respon dengan anggukan kepala oleh peserta rapat.

3. Maksim Pujian.

Prinsip kesantunan Leech dalam Rahardi (2010:59) approbation maxim (maksim kemurahan/Pujian) adalah menuntut setiap peserta pertuturan untuk memperkecil kecaman pada orang lain dan pujilah orang lain sebanyak mungkin. Penjelasan mengenai wujud tuturan yang menerapkan maksim pujian antara perangkat desa dengan perangkat desa dapat dilihat pada data 5 .

Data 5

On/Rek/ video_20191001_153516 $-2$

Situasi : Rapat membahas tentang Jumat Bersih

Waktu : 1 Oktober $2019 / 10: 53$

"Kalian mempunyai tingkat pendidikan yang lebih tinggi dari pada saya”.

Tuturan tersebut disampaikan oleh bapak Suparno Sekdes Desa Pondok Pabrik di depan perangkat Desa Pondok Pabrik. Tuturan seperti yang di atas mengandung maksim pujian. Maksim pujian tersebut muncul merupakan gambaran bahwa perangkat desa pondok pabrik memiliki tingkat pendidikan tingkat Sarjana yang lebih tinggi dari tingkat pendidikan Sekdes sendiri (Data 5) Kalian mempunyai tingkat pendidikan yang lebih tinggi dari pada saya. Membuktikan bahwa Sekdes Desa Pondok Pabrik berusaha memperkecil kecaman pada orang lain dan pujilah orang lain sebanyak mungkin. Dapat disimpulkan tuturan (Data 5) mengandung maksim pujian.

4. Maksim Kesederhanaan.

Prinsip kesantunan Leech dalam Rahardi (2010:59) Modesty Maxim (maksim keserderhanaa) adalah menuntut setiap peserta pertuturan untuk meminimalisir pujian terhadap diri sendiri dan memaksimalkan kecaman untuk diri sendiri. Penjelasan mengenai wujud tuturan yang menerapkan maksim kesederhanaan antara perangkat desa dengan perangkat desa dapat dilihat pada data 20. Berikut penjelasannya.

Data 20

On/Rek/video_20191001_153516-2

Situasi : Kelengkapan Data

Administrasi

Waktu : 7 Oktober 2019/25:58

"Ada hikmahnya jika kita mengutip sampah karena bermanfaat bagi orang lain".

Tuturan tersebut disampaikan oleh bapak Suparno Sekdes Desa Pondok Pabrik di depan perangkat Desa Pondok Pabrik. Tuturan seperti yang di atas mengandung maksim kerendahan hati. Maksim kerendahan hati tersebut muncul menanggapi pelaksanaan Jumat bersih yang mendapat apresiasi dari Kecamatan dan dapat dijadikan contoh untuk 14 desa. (Data 20) Ada hikmahnya jika kita mengutip sampah karena bermanfaat bagi orang lain. Membuktikan bahwa Sekdes Desa Pondok Pabrik berusaha meminimalisir pujian terhadap diri sendiri dan memaksimalkan kecaman untuk diri sendiri. Dapat disimpulkan tuturan (Data 20) mengandung maksim kesederhanaan. Tuturan bapak Suparno Sekdes Desa Pondok Pabrik di respon dengan anggukan kepala oleh peserta rapat.

5. Maksim Kesepakatan.

Prinsip kesantunan menurut

Leech dalam Rahardi (2010:59)

Agreement Maxim (Maksim 
Kesepakatan) adalah menghendaki agar setiap penutur dan lawan tutur memaksimalkan kesetujuan di antara mereka dan meminimalkan ketidaksetujuan di antara mereka. Penjelasan mengenai wujud tuturan yang menerapkan maksim kesepakatan antara perangkat desa dengan kepala desa dapat dilihat pada data 24 serta wujud tuturan yang menerapkan maksim kesepakatan. Berikut penjelasannya.

Data 24

On/Rek/ video_20191001_153516-2

Situasi : Kelengkapan Data

Administrasi

Waktu : 7 Oktober 2019/10:43

"Saya minta tolong untuk membuat KTP para warga harus melengkapi persyaratan".

Tuturan tersebut disampaikan oleh Bapak Noto Kepala Desa Pondok Pabrik di depan perangkat Desa Pondok Pabrik. Tuturan seperti yang di atas mengandung maksim kesepakatan. Maksim kesepakatan tersebut muncul saat membahas kelengkapan administrasi yang ada di Desa Pondok Pabrik masih terkesan semrawut. (Datab 24) Saya minta tolong untuk membuat KTP para warga harus melengkapi. Membuktikan bahwa Bapak Noto Kepala Desa Pondok Pabrik berusaha memaksimalkan kesetujuan di antara mereka dan meminimalkan ketidaksetujuan di antara mereka. Dapat disimpulkan tuturan (Data 24) mengandung maksim kesepakatan. Bapak Noto Kepala Desa Pondok Pabrik di respon oleh bapak Zulkarnain bahwa masih banyak warga yang belum melengkapi persyaratan untuk pembuatan KTP sehingga proses pengurusannya akan menyulitkan warga sendiri.

6. Maksim Kesimpatian.

Prinsip kesantunan menurut

Leech dalam Rahardi (2010:59)

Sympathy maxim (maksim kesimpatian)

mengharuskan semua peserta pertuturan untuk memaksimalkan rasa simpati dan meminimalkan rasa antipasti kepada lawan tuturnya. Penjelasan mengenai wujud tuturan yang menerapkan maksim kesimpatian antara desa dengan kepala desa dapat dilihat pada data 16 yang menerapkan maksim kesimpatian antara perangkat desa dengan perangkat desa, berikut penjelasannya.

Data 16

On/Rek/video_20191001_153516-2

Situasi : Rapat membahas tentang Jumat Bersih

Waktu : 1 Oktober 2019/15:53

"Yang penting kita ikhlas, saya sendiri kalau berjalan dan menemukan sampah saya kutipin”.

Tuturan tersebut disampaikan oleh bapak Suparno Sekdes Desa Pondok Pabrik di depan perangkat Desa Pondok Pabrik. Tuturan seperti yang di atas mengandung maksim kesimpatian. Maksim kesimpatian tersebut muncul merupakan tanggapan atas wacana bahwa sampah yang dibuang sembarangan akan berdampak pada kesehatan, aromanya dapat menimbulkan penyakit (Data 16) Yang penting kita ikhlas, saya sendiri kalau berjalan dan menemukan sampah saya kutipin. Membuktikan bahwa Sekdes Desa Pondok Pabrik berusaha memaksimalkan rasa simpati dan meminimalkan rasa antipasti kepada lawan tuturnya. Dapat disimpulkan tuturan (Data 16) mengandung maksim kesimpatian.

Berbicara adalah tindak tutur yang membutuhkan prinsip kesopanan. Apa bila seseorang bertutur tidak sopan, berarti ia melanggar prinsip kesantunan seperti yang dijelaskan oleh Chaer (dalam Kurnia Safitri, 2014:17). Pada penelitian ini terdapat 3 tutur yang melanggar prinsip kesantuan yaitu:

Data 6

On/Rek/ video_20191001_153516-2 
Situasi : Rapat tentang Kinerja Aparat Desa

Waktu : 20 September 2019/17:16

"Tiap rapat yang dibahasa itu saja akan tetapi tidak ada perubahan".

Tuturan tersebut disampaikan oleh bapak Yusri Zulkarnein Kepala Dusun Rajawali di depan perangkat Desa Pondok Pabrik. Penutur ketika bertutur kadang kala disertai dengan dorongan rasa emosi yang begitu berlebihan sehingga ada kesan bahwa penutur marah kepada lawan tuturnya. Tuturan yang diungkapkan dengan rasa emosi oleh penuturnya akan dianggap menjadi tuturan yang tidak santun.

Data 11

On/Rek/video_20191001_153516-2

Situasi : Rapat membahas tentang Jumat Bersih

Waktu : 1 Oktober 2019/27:12

"Hei, tugas kalian sudah siap atau belum jangan meminta hak tanpa melakukan kewajiban"

Tuturan tersebut disampaikan oleh bapak Suparno Sekdes Desa Pondok Pabrik di depan perangkat Desa Pondok Pabrik. Kritik kepada lawan tutur secara langsung dan dengan menggunakan katakata kasar akan menyebabkan sebuah pertuturan menjadi tidak santun atau jauh dari peringkat kesantunan. Kritik yang diberikan secara langsung dan menggunakan kata-kata kasar dapat menyinggung perasaan lawan tutur, sehingga dinilai tidak santun.

Data 12

On/Rek/video_20191001_153516-2

Situasi : Rapat membahas tentang Jumat Bersih

Waktu : 1 Oktober 2019/03:39

"Mukanya bersih tapi rumahnya seperti itu, kotor karena banyak sampahnya"

Tuturan tersebut disampaikan oleh bapak Suparno Sekdes Desa Pondok Pabrik di depan perangkat Desa Pondok Pabrik. Kritik kepada lawan tutur secara langsung dan dengan menggunakan katakata kasar akan menyebabkan sebuah pertuturan menjadi tidak santun atau jauh dari peringkat kesantunan. Kritik yang diberikan secara langsung dan menggunakan kata-kata kasar dapat menyinggung perasaan lawan tutur, sehingga dinilai tidak santun.

Tabel distribusi frekuensi prinsipprinsip kesantunan tindak tutur percakapan rapat dinas antara perangkat desa dengan kepala desa dapat dijelaskan pada tabel berikut:

\section{Tabel 1 Distribusi Frekuensi Tindak Tutur Percakapan Rapat Dinas Antara Perangkat Desa dengan Kepala Desa}

\begin{tabular}{|l|l|c|c|}
\hline No & \multicolumn{1}{|c|}{ Prinsip Kesantunan } & Frekuensi & Persentase \\
\hline 1 & Maksim kebijaksanaan & 5 & 20 \\
\hline 2 & Maksim Kedermawanan & 3 & 12 \\
\hline 3 & Maksim Pujian/penghargaan & 2 & 8 \\
\hline 4 & Maksim Kesederhanaan & 1 & 4 \\
\hline 5 & Maksim Kesepakatan & 8 & 32 \\
\hline 6 & Maksim kesimpatian & 5 & 20 \\
\hline & Jumlah & $\mathbf{2 5}$ & $\mathbf{1 0 0}$ \\
\hline
\end{tabular}

Berdasarkan tabel 5 di atas dapat dilihat dalam tindak tutur percakapan rapat dinas antara perangkat desa dengan Kepala Desa yang memenuhi kaidah kesantunan dari Leech dapat disimpulkan 
bahwa maksim kesepakatan lebih dominan muncul dalam 4 kali rapat yang di adakan

\section{Penutup}

Berdasarkan hasil penelitian dan pembahasan, maka dapat disimpulkan bahwa penelitian mengenai Kesantunan Berbahasa Perangkat Desa Pondok Pabrik Kota Langsa tuturan yang mengandung maksim kesepakatan lebih dominan dibandingkan maksim kebijaksanaa, maksim kedemawanan, maksim pujian, maksim kesimpatian,dan maksim kesederhanaan. Hal ini dikarenakan pada situasi rapat bertujuan untuk memecahkan atau mencari jalan keluar suatu masalah yang harus dirundingkan/didiskusikan secara bermusyawarah, serta ditemukan sedikit tuturan yang melanggar prinsip kesantuan berbahasa. Penulis menyadari bahwa penelitian tentang Kesantunan Berbahasa Perangkat Desa Pondok Pabrik Kota Langsa masih belum lengkap dan masih terbuka untuk diadakan penelitian lebih lanjut mengenai kesantunan ataupun persoalan lain yang dapat diungkap dalam kaitannya dengan kesantunan berbahasa. Misalnya, mengenai kesantunan berbahasa perangkat desa dengan masyarakat. Oleh karena itu, mudah-mudahan melalui penelitian ini dapat mendorong penelitipeneliti lain untuk melanjutkannya dengan mencari hal-hal yang belum terungkap di dalam penelitian yang dilakukan pada penelitian sebelumnnya.

\section{Daftar Rujukan}

Budiwati,Tri Rina. 2017. Kesantunan Berbahasa Mahasiswa Dalam Berinteraksi Dengan Dosen di Universitas Ahmad Dahlan: Analisis Pragmatik. The 5th Urecol ProceedingSastra Inggris, Universitas Ahmad DahlanYogyakarta.

Dari, Ayu Wulan, Dian Eka Chandra W dan Marina Siti Sugiyati. 2017. Analisis Kesantunan Berbahasa Pada Kegiatan di Pondok Pabrik.

Pembelajaran Kelas VIII E SMPN 2 Kota Bengkulu Tahun Ajaran 2016/2017. Jurnal Korpus , Volume 1, Nomor 1, Agustus 2017.

Hartanti. 2013. Etika Berbahasa. https://bahasauhamka.wordpress.co m/2013/01/26/etika-berbahasa/

Mislikhah, St. 2014. Kesantunan Berbahasa.Ar-Raniry:

International Journal of Islamic Studies Vol. 1, No.2, Desember 2014.

Pratamanti, Enggar Dhian. 2017. Kesantunan Berbahasa Dalam Pesan Whatsapp Mahasiswa Yang Ditujukan Kepada Dosen. Dinamika Soaial Budaya, Vol 19, No 2, Desember 2017.

Rahardi, Kunjana. 2010. Pragmatik; Kesantunan Imperatif Bahasa Indonesia. Jakarta: Erlangga.

Safitri, Kurnia. 2014. Penyimpangan Prinsip Kesantunan Berbahasa Dalam Interaksi Belajar Mengajar Bahasa Indonesia Siswa kelas VIII SMP Negeri 3 Sewon. Skripsi. Universitas Negeri Yogya

Sartini. 2016. Strategi Kesantunan Berbahasa Diaspora Orang Bali di Jawa Timur. Jurnal Vol (16) (2)

Sugiyono. 2018. Metodologi Penelitian Kuantitatif, Kualitatif dan R\&D . Bandung: Alfabetha.

Suhartono. 2016. Etika Berbahasa Dalam Pelayanan Publik. Jurnal. Semarang UPBJJ

Yule. 2014. Pragmatik. Yogyakarta: Pustaka Pelajar

Zaim, M. 2014. Metode Penelitian Bahasa Pendekatan Struktural. Padang: UNS Press 
Jurnal Samudra Bahasa

Volume 3 Nomor 1

Juni 2020 